\title{
Scenario of Indian Agricultural Export of Major Agricultural Commodities in the Post WTO Regime
}

\author{
Anil Bhuimali ${ }^{1}$ and Debasish Chakraborty ${ }^{2}$
}

${ }^{1}$ Vice Chancellor, Raiganj University, Raiganj, West Bengal, India

${ }^{2}$ Department of Economics, University Of North Bengal, West Bengal, India

*Corresponding author: chakrabortydebasish789@gmail.com

\begin{abstract}
Agriculture was included under WTO through AOA negotiation in 1995. Today around 17\% of India's GDP (India's GDP is US \$ 2.545 trillion) is from agricultural sector and 12\% of total export earning which is substantial amount to have a huge impact on nation's economy if any change occurs in the world economy. $55 \%$ of total employment comes from agricultural sector. About $70 \%$ people directly or indirectly depends on it and about $43 \%$ of India's total land is covered by agricultural sector. India became self sufficient in Food grain production decades after independence. It is now producing around 280 million metric tons of food grains in the world and ranks first in many major agricultural food crops in the world. But after liberalization phase started in the world with WTO (1 ${ }^{\text {st }}$ Jan 1995) and AOA many thing has dramatically changed in agricultural sector of India, for example, Total yield or Output, Farm Pattern, Agricultural Infrastructure, Annual Compound Growth rate in Production \& Export, Imports, Prices of major agricultural food and non food materials, Export Competitiveness, quantitative restrictions, tariff \& non tariff barriers, export subsidy, domestic support, sanitary \& Phyto sanitary measures, Geographical Indication, Trade related intellectual property rights etc. WTO which has replaced GATT (general agreement on trade \& tariff 1947-1994) was established for multilateral trade agreements among nations is committed to Free trade, Non discriminations in trade, Removal of Quantitative Restrictions, non tariff barriers between nations and free $\&$ fair competitions in trade among nations ${ }^{[12]}$. India who is a founding member among 162 member nations of WTO, maintaining and obeying most of the clauses related to developing nations in WTO charters. Our study have looked into the norms and rules of WTO, how far India has followed those rules and what are the consequences has happened to India's agricultural trade since WTO and a comparison between the pre \& post WTO era in trading of Indian agricultural commodities. And our Findings in this small study is that India has benefitted in many extent in agricultural trade the post liberlisation or post WTO period and trade indicators are positive in many extent. This thing has surfaced many issues that may be taken for study and research. This paper like many papers compares Indian agricultural export in the pre \& post WTO era but at the same time it also took into consideration the commodity wise trade and both convergence \& divergence in Indian agricultural export. This paper reveals that India was
\end{abstract}


specializing in agricultural commodity export in the pre WTO period but it left it and started gaining its expertise in agricultural commodity export in the post WTO era. So WTO has made mixed impact on Indian agricultural commodity export.

Keywords: WTO, Agricultural Trade, Import \& Export growth etc.

The Indian agricultural sector is much diversified and self reliant after. Around 15\% (2015-16) of India's total GDP generates from agricultural sector, and about $60 \%$ of its total population depend on agriculture for employment. India's total agricultural production was 280 million tonnes in 2015-16 as compare to 52 million tonnes in 1950-51. It is the result of Green revolution and constant supply of public Investment in developing agricultural infrastructure in the country. Then also with ever growing huge burden of population (1320 million in recent published data) and increasing demand for job \& foodstuff both India needs a vibrant agricultural sector with high growth rate in Agricultural export share in world trade. Though India has a good potential in agricultural trade then also as Indian agricultural trade exhibits fluctuations which is more than any other trade ${ }^{[1]}$. India needs to take care of it. Though enormous competition has emerged during the last decades among the countries of the world in agricultural trade, the WTO has tried to develop \& provide several measures for fairly competitive environment for fair trade where there are fewer barriers \& restrictions but more openness and accessibility toward other countries markets. Though there is violations of WTO framed regulations by many developed countries for their favour, there are still enormous possibilities for agricultural trade to develop ${ }^{[2]}$. This paper tries to analyse India's situation, Potential and probable possibilities in development of agricultural trade.

\section{Objective of the Study}

The objective of the paper to find out:

1. India's position in the world in agricultural trade \& export.

2. That the total agricultural exports of Indian agricultural trading commodities either increased or decreased during the post WTO period. And also the amount of Convergence \& divergence In Agricultural commodity export.

3. That Whether India became vulnerable to cheap world agricultural imports in the post WTO phase.

4. How India has reformed or reshaped its agricultural trading policies in order to protect its domestic market and at the same time take benefit from new international multilateral trade agreements.

\section{Data and Methodology}

The present study is based on secondary data. These data has been collected from various secondary data sources which includes government data from Ministry of Agriculture \& Cooperation, NSSO reports, Agricultural census data, Beauro of Economics \& Statistics, CMIE and other public reports, state government department of agriculture, internet website www.wto.org, Economic survey of India, (GOI) data like Ministry of agriculture, A.P.E.D.A., FAO trade \& production year books, Indian Journal of Agricultural marketing and Indian Journal of Agricultural Economics, Related data published on E.P.W.S., Ministry of commerce Government of India and various papers published on interested topics. 
Reference period of the study is taken from 2000-2002 to 2012- 3 (post WTO period). This research study would discuss the comparative performance of trade of major Indian agricultural commodities during post WTO regime. It would analyze the export performance and competitiveness of major Indian agricultural commodities during post -WTO regime.

$$
N P C i=P i^{d} / P i^{w}
$$

Where, NPC $i=$ Nominal protection coefficient of commodity $i$.

$P_{i}^{d}=$ Domestic price of commodity $i$.

$P_{i}^{w}=$ World reference price of commodity $i$, adjusted for transportation, handling and marketing expenses.

Here, NPC $<1$ indicates the commodity is exportable and NPC $>1$ indicates that the commodity is importable.

\section{REVIEW OF LITERATURE}

Empirical Studies: Some important studies done recently have shown that terms of trade in agricultural trade declines in many very poor countries (Least Developed Countries as mentioned by the UN) especially Sub-Saharan African countries. These heavily indebted marginalized countries fell in the group where few agricultural commodities comprise about $90 \%$ of their total export making them marginal player in global trade (Watkins and Fowler 2002; FAO 2004; UNCTAD 2004). One study recently done by FAO show the terms of trade has declined to about half of these developing nations. A different opinion regarding TOT is found in case of BRICS and ASEAN nations by policy makers ${ }^{[9]}$.

One major finding in recent studies it has been revealed that since 1950 to 2010 it is found that real prices for agricultural exports of developing countries exports declined comparing to the relative prices of Imports of their manufactured goods by almost 70 per cent (FAO 2004). The DCs mostly rely on exporting synthetic products and protectionism in domestic import of agricultural goods from LDCs. That is why the third world countries united drawing attention of the world in the WTO conference of CANCUN in 2003 on the pricing problems associated with the commodities. Though the chance is very less that the final outcome of the DOHA round will end with proper solution to the LDCs long standing grievances ${ }^{[8]}$. The 12 OECD countries controls about $65 \%$ of the world's total Agricultural trade which was reflected in the book 'Negotiating the Future of Agricultural Policies' by Bilal (2001). Though the U.S., EU, Canada, and Australia have proven production advantages in wheat and other cereals and other temperate zone commodities, India has benefitted from its good comparative advantage in many agri-commodities ${ }^{[18]}$.

Market should be open rather than manipulated being the narrative and contention of the Developed world particularly the USA and EU, these countries always tried to create pressure on developing nations for maintaining open market norms but they themselves violated these norms time and time again by putting tariff barriers, QRs, Anti Dumping measures and other different types of protectionist measures on importing agricultural goods from developing nations ${ }^{[17]}$. Here India's role is very crucial and different as India being in a significantly comparatively advantageous position (India's agricultural export has risen multiple times after the WTO to the Developed nations) and being a developing nation has always tabled argument against the DCs for the discriminations to LDCs by them and protectionist measures 
adopted by them ${ }^{[13]}$. India's role has been positive and constructive in the post trade liberalization era for multilateral free and fair trade.

There has been substantial empirical literature on various aspects of this research paper. Where some of the researchers have expressed their opinion which is as follows:

$\square$ Matthew Saunders and Rolf Mirus (2003): They argued in favour of free trade and against protectionism and they argued in favour of proposed changes to anti dumping agreements. And even they have argued in favour of Proposed Changes to the Agreement on Subsidies and Countervailing Measures.

$\square$ Peter M. Rosset (2004) : According to him the three basic pillars of AOA are (I) Market access (ii) Export subsidy (iii) Domestic support. He showed a lot in the media about "trade wars" between the U.S. and Europe, about steel quotas and cotton subsidies, and about how dissatisfied poor countries are with global trade rules.

$\square$ R S Deshpande, J Prachitha (2005): These persons have put forwarded impacts of WTO policies on the Indian state of Karnataka, where according to their study the cell recommends that India's concern on food security, rural employment and need to protect the environment should not be neglected in a purely market-oriented 82 approach. They argued that it is necessary to adopt market-friendly approach without government support.

$\square$ Ashok Gulati and A. Sharma (1994): Both of these two authors have explained the upcoming situation of Indian agriculture under the WTO regime. According to them Indian agriculture will not gain much in the open trade environment under the free trade regime of $\mathrm{WTO}^{[4]}$.

$\square$ Martin Khor(2004): He has studied and worked on the topic "The WTO Agriculture Agreement: Features, Effects, Negotiations, and What is at Stake". Here his paper starts with a brief summary of the main features of the commitments made by Members in the World Trade Organization's Agreement on Agriculture (AOA).

$\square$ Samar Datta (2000). According to S. Dutta, India is self sufficient in competing with the world in rice export. And India needs not to worry about the competitive environment under the WTO regime other than price manipulation of the rival exporters of rice. India should stay at its zero import duty position on rice ${ }^{[5]}$.

Rani, Pooja (2015): In this paper “A Study of WTO and Agriculture Sector in India” they have explained the global trade that how it is well connected. What they have found regarding WTO and India is that after engaging with WTO India has increased its domestic production and export of agricultural product and it has been helpful in increasing employment level of the country in agricultural sector. According to them Indian agricultural growth will take momentum in the coming future as investments are taking place in agricultural infrastructure in the country ${ }^{[7]}$.

$\square$ Deepika MG (2005): In her theses named "Changing Trade Scenario in Agriculture and its Implications for the Indian Economy" she wanted to express that tough trade libcralisation assumed a special significance in the context of economic reforms in the late eighties and early nineties in India, they were not directly made applicable to the agricultural sector due to its unique characteristics $^{[11]}$. 
Hedayat Hosseinzadeh (2008): The main object of his research was to examine the economic effects of Globalization and the trade openness on Iran's agricultural sector. He reviewed the agricultural exports and imports policies in Iran during the period from 1980 to 2004 . He surveyed the impact of economic liberalization and privatization policy on the performance of agricultural export and import during 1980-2004. He studied the future prospects of agricultural products, exports and imports.

$\square$ Umesh, K.B., Akshara M., Shripad Bhat, Harish Kumar, K. and Srinivasan, S.M. (Beijing 2009): In 2009 these people have worked together for presenting paper in Economists Conference, Beijing, China, August 16-22, 2009 on the topic "Performance Analysis of Production and Trade of Indian Silk under WTO Regime” where they have showed that India is the second largest producer of silk and also the largest consumer of silk in the world having a strong tradition bound domestic market. In this paper, they estimated growth functions for India's aggregate production and trade parameters using annual data from 1984/85 to 2006/07.

$\square$ Andre M. Nassar, Diego Ures (2009): In their IFPRI Discussion paper named “Brazil: Shadow WTO Agricultural Domestic Support Notifications" where they has argued that Brazil is presenting itself as being in a comfortable position with respect to domestic support in the Doha Round negotiations, and our analysis confirms this position. New rules are necessary to guarantee that policies oriented to create demand for biofuels will not jeopardize world agricultural markets. WTO rules, however, must be improved in order to capture the specific situations of biofuels, which are not the same as other agricultural commodities.

$\square$ Ranga M. \& Sharma, D. (2014): in their paper "WTO and Indian Agriculture” showed that if aspects there exists no real insecurity, related to WTO norms (like market access, domestic support, export subsidy, removal of tariff, provisions related to IPR, non tariff barriers etc) be dealt with good vigilance there exists no real threats or insecurity on agricultural trade ${ }^{[2]}$.

$\checkmark$ Renuka Mahadevan (2003): In her paper named "Productivity Growth in Indian Agriculture: The Role of Globalization and Economic Reform" she has explained that although India missed the opportunity to open up two decades ago, its attempts to do so now must be regarded as better late than never. Having realized that globalization is a necessary but not a sufficient condition for high growth production, India has undertaken economic reforms, both internal and external.

$\checkmark$ Mithilesh Kumar (2006): In his work titled “Temporal Changes in Dairy Industry in India” he has explained that the dairy sector occupies a dominant place in providing food, income, employment and foreign exchange to the Indian economy. The positive trend in export and negative trend in imports was observed due to the success full implementation of Operation Flood and set of Government policies regarding international trade.

$\square$ Kavitha, N. V. and Reddy, N. Suma (2015): Their paper named " $A$ Study on the Commodity Derivatives Market and Development in India - Towards Sustainability” was based on the agricultural commodity trading in India. They have shown on their paper that how the Government of India has initiated reforms in the commodity market of agriculture so as to solve the issue of dependant farmer or people using old agricultural exchange mechanism of agricultural commodity trade.

Vijayakumar B.K. (2007): Mr. Vijayakumar worked on impact of WTO on the Indian state of Karnataka's cereal production and his research was named "Changes in Cereals Economy of 
Karnataka Pre and Post WTO Analysis" where he analysed that the global competitiveness of cereals (rice and maize) and their economics of production over the period of time in Karnataka. In his study, he has made an attempt to estimate NPC, DRC, direction of trade, integration between domestic and international prices and supply response of rice and maize. The findings of the study would help the planners and the policy makers to formulate appropriate agricultural development, export and stabilization policies for the state as a whole.

$\square$ Sheshagiri, B. \& Honkan, G.G. (2011): This paper named "Impact of W.T.O on Indian Agriculture: Performance and Prospects" showed that the developed countries which have high tariff on agricultural import from countries India should bring down their tariff rate in order to improve agricultural commodity trade. Their study highly suggests that there is huge scope in increasing agricultural trade between developed and developing nations like India even without resorting to paradigm shift to new improved technology or policy regarding that ${ }^{[10]}$.

Nitin Vinod Dacha (2005): In his paper "Prospects of the Uruguay Round Agreement on Agriculture and the Reality of its Impact on Indian Agricultural Trade" he showed that Inconsistencies within the developed countries agenda concerning agricultural liberalization have stalled the progress of the process at least until the next trade round. It seems that developed countries only concede when it is convenient and have protected themselves exclusively at times through the use of such measures as the 'special safeguard' provision and the 'peace clause'.

$\square$ Niranjan, S.K. (2016) \& Ranjith, D. (2016): In their work they both analysed the pattern of import and export since the beginning of WTO regime, where they found Indian imports of agricultural goods were cheaper as most of the exporting nations were giving huge subsidies to their domestic agricultural production \& export. Both of them concluded that India's post WTO trading experience of agricultural commodities was not much satisfactory as compare to the pre WTO phase.

口 Shukla, S.P. (2000): In his paper titled "From GATT to WTO and Beyond" he intended to show that to analyse the evolution of the international trading system from its inception as the GATT in 1947 to its latest incarnation in the form of WTO, comprising the complex array of agreements forming its substance and mandate. His study focuses on the adequacy and in adequacy of the system as it evolved and functioned in an environment of changing international economic and political reality.

\section{Trend of Agricultural Trade performance of India from the inception of WTO}

Indian agricultural trade performance in the pre WTO period (if we take 10 years before the WTO) was quite satisfactory i.e. the volume of trade in agriculture was approximately $18 \%$ of the total export at that time. The agricultural commodity export in the post WTO period has been inconsistent as it has been fluctuating since $1995^{[14]}$. It has never been stable since then. For example It was $19.14 \%$ in 1996 and rose up to its highest level i.e. nearly $21 \%$ of total export of the country in 1997. But from 1998 it has been fluctuating rather declining. For example it was around $10 \%$ of the total export in 2006 as it was declining continuously since 1998. After that a series of agricultural export fluctuation has been occurring in Indian economy every consecutive year. For example It fluctuated and it was recorded around 13\% in 2016-17 (latest). If we compare this value with the pre WTO record then it is quite dissatisfactory. It is much lower than the pre WTO estimation. Though the compound annual growth rate of post WTO 
period was higher than that of the pre WTO era,In the post WTO period, in 2015 the CAG of agricultural export was $12.35 \%$ as compare to $7.16 \%$ in 1996$)^{[3]}$. Thus, it is visible that an average annual growth in agricultural commodity export in the post WTO period is declining and much less than the Pre WTO period, which implies a negative impact of WTO on Indian agricultural commodity export. Though WTO and AOA was meant to establish to flourish and improve fair growth of trade. In the following we shall discuss and focus on some important tabular expression of data regarding Indian agri-trade during and prior the liberalisation phase, which will help us understanding the role of WTO policies and AOA on Indian agricultural export trade on selected and multiple commodities ${ }^{[19]}$.

Table 1: Indian Agricultural commodity Export (A Comparison between PRE \& Post WTO era) (Values expressed in terms of US dollar in millions)

Pre-WTO Period

\begin{tabular}{ccccc}
\hline Year & Total Export & $\begin{array}{c}\text { Agricultural } \\
\text { Export }\end{array}$ & $\begin{array}{c}\text { Agricultural Export } \\
\text { Growth rates }\end{array}$ & $\begin{array}{c}\text { Percentage share of } \\
\text { Agriculture in total Export }\end{array}$ \\
\hline $1990-91$ & 18146 & 3356 & 17.58 & 18.4 \\
$1991-92$ & 17849 & 3207 & -4.5 & 17.94 \\
$1992-93$ & 18552 & 3133 & -2.1 & 16.91 \\
$1993-94$ & 22230 & 4031 & 28.4 & 18.11 \\
$1994-95$ & 26339 & 4220 & 4.9 & 16.02 \\
Average & 20623.2 & 3589.4 & 8.86 & 17.5 \\
Coefficient of Variation & 17.7 & 13.98 & & 5.7 \\
Compound Annual & 10.12 & 7.16 & & -2.69 \\
Growth Rate & & & & \\
\hline
\end{tabular}

\section{Post- WTO Period}

$\begin{array}{ccccc}1995-96 & 31795 & 6082 & 43.9 & 19.13 \\ 1996-97 & 33470 & 6863 & 12.8 & 20.5 \\ 1997-98 & 35006 & 6626 & -3.4 & 18.93 \\ 1998-99 & 33219 & 6035 & -11.3 & 18.17 \\ 1999-2000 & 36822 & 5608 & -7.0 & 15.68 \\ 2000-01 & 44560 & 5973 & -1.7 & 13.5 \\ 2001-02 & 43827 & 5901 & 14.1 & 13.5 \\ 2002-03 & 52719 & 6710 & 12.2 & 12.8 \\ 2003-04 & 63843 & 7533 & 11.7 & 11.8 \\ 2004-05 & 83536 & 8475 & 20.5 & 10.1 \\ 2005-06 & 103091 & 10214 & 24.0 & 9.9 \\ 2006-07 & 126414 & 12683 & 45 & 10.3 \\ 2007-08 & 163132 & 18432 & -4.8 & 11.3 \\ 2008-09 & 185295 & 17534 & 1.1 & 9.5 \\ 2009-10 & 178751 & 17735 & 39.2 & 10.0 \\ 2010-11 & 251136 & 24696 & 51.52 & 9.9 \\ 2011-12 & 217664 & 37420.8 & 13.19 & 17.19 \\ 2012-13 & 300400.7 & 42356.50 & 2.36 & 14.1 \\ 2013-14 & 314415.7 & 43357.92 & -9.38 & 13.79 \\ 2014-15 & 310352 & 39290.56 & -12.18 & 12.66 \\ 2015-16 & 262003.7 & 34503.42 & & 13.17\end{array}$




\begin{tabular}{|c|c|c|c|c|}
\hline Average & 136735.81 & 17334.72 & 11.82 & 13.62 \\
\hline $\begin{array}{l}\text { Coefficient of } \\
\text { Variation }\end{array}$ & 75.82 & 79.25 & & 25.20 \\
\hline $\begin{array}{l}\text { Compound Annual } \\
\text { Growth Rate }\end{array}$ & 14.62 & 12.35 & & 2.00 \\
\hline
\end{tabular}

Source: RBI, Handbook of Statistics on Indian Economy

Though the table 1 shows that Indian agricultural export has increased over the years from US $\$ 3590$ million in the Pre WTO era to US \$ 17335 million in the post WTO era, the amount of average share of agricultural export has gone down from $17.5 \%$ in the pre WTO era to $13.62 \%$ in the post WTO era[6]. In this time the CV (coefficient of Variation) has showed much variation, like it was 5.7 in the pre WTO period and become 25.20 in the post WTO era ${ }^{[15]}$. This may be as a result of increase in export of nonagricultural commodities rather than agricultural commodities.

Table 2: Five yearly Compound Annual Growth rate (CAGR) of Indian Agricultural Import \& Export commodities.

\begin{tabular}{ccc}
\hline Period & Agricultural Export percentage & Agricultural Import percentage \\
\hline $1991-1995$ & 21.78 & 48.96 \\
$1996-2000$ & 5.55 & 28.51 \\
$2001-2005$ & 9.77 & 17.21 \\
$2006-2010$ & 16.07 & 29.00 \\
$2011-2015$ & 31.71 & 22.04 \\
\hline
\end{tabular}

Source: Ministry of Agriculture, Government of India, New Delhi

The table 2 shows that agricultural export was adversely affected after the WTO during the early years after India's signing in WTO, but there after again Indian agricultural sector became competitive in the global market by raising the export level. In that time the import also declined sharply but it further started increasing since 2006-07.

Table 3: Percentage Share of Indian Agricultural exports in World Agricultural Exports and value of Indian Agricultural Exports (Value Expressed in US \$ in Millions)

\begin{tabular}{cccc}
\hline $\begin{array}{c}\text { Year } \\
\text { Pre WTO }\end{array}$ & World & India & $\begin{array}{c}\text { India's Share in World } \\
\text { agricultural Exports }\end{array}$ \\
\hline 1990 & 414723 & 3506 & 0.80 \\
1991 & 418236 & 3361 & 0.80 \\
1992 & 447887 & 3676 & 0.82 \\
1993 & 429335 & 4167 & 0.97 \\
1994 & 500913 & 4399 & 0.88 \\
Average & 442218.8 & 3821.8 & 0.85 \\
CAGR(1990-1994) & 4.12 & 6.92 & 3.91 \\
\hline Post WTO & & & \\
\hline 1995 & 583200 & 6322 & 1.0 \\
1996 & 592870 & 7040 & 1.18 \\
1997 & 589230 & 6863 & 1.16
\end{tabular}




\begin{tabular}{|c|c|c|c|}
\hline 1998 & 560560 & 6235 & 1.11 \\
\hline 1999 & 543820 & 5835 & 1.07 \\
\hline 2000 & 552250 & 6401 & 1.15 \\
\hline 2001 & 554130 & 6265 & 1.13 \\
\hline 2002 & 582530 & 7025 & 1.20 \\
\hline 2003 & 683336 & 7935 & 1.16 \\
\hline 2004 & 788084 & 8588 & 1.08 \\
\hline 2005 & 851847 & 10134 & 1.18 \\
\hline 2006 & 943676 & 12353 & 1.30 \\
\hline 2007 & 1127667 & 16020 & 1.42 \\
\hline 2008 & 1348136 & 21251 & 1.57 \\
\hline 2009 & 1181391 & 16384 & 1.38 \\
\hline 2010 & 1366469 & 23106 & 1.69 \\
\hline 2011 & 1659524 & 34323 & 2.06 \\
\hline 2012 & 1656711 & 42356.50 & 2.56 \\
\hline 2013 & 1744833 & 43357.92 & 2.48 \\
\hline 2014 & 1765405 & 39290.56 & 2.23 \\
\hline 2015 & 1568337 & 34503.42 & 2.2 \\
\hline Average & 1011620.76 & 17218.50 & 1.49 \\
\hline CAGR(1995-2015) & 7.26 & 11.90 & 4.46 \\
\hline
\end{tabular}

Source: WTO, International Trade Statistics.

The Table 3 shows that India's average exports share in the world in the Post WTO period became as high as $1.49 \%$, which was quite low $(0.85 \%)$ in the pre WTO era. This means that there has been tremendous shift in share of Indian Agricultural export in the post WTO period. Other than this India's share of agri -export in 1995 was $1 \%$ which had improved to $1.69 \%$ in 2010 and $2.06 \%$ in 2011 . This sudden increase of share of Agricultural export globally brought India to leading exporters of agricultural commodities in the World. Though the share has gradually declined from $2.56 \%$ in 2012 to $2.20 \%$ in 2015 with negative growth in these consecutive years, India still holds a good position in agricultural export market.

Table 4: Share of Few Agricultural Commodities in Percentage in India's Total Exports in Pre-WTO Period

\begin{tabular}{ccccccc}
\hline Commodities & $\mathbf{1 9 9 0 - 9 1}$ & $\mathbf{1 9 9 1 - 9 2}$ & $\mathbf{1 9 9 2 - 9 3}$ & $\mathbf{1 9 9 3 - 9 4}$ & $\mathbf{1 9 9 4 - 9 5}$ & Average \\
\hline Tea & 3.3 & 2.8 & 1.8 & 1.5 & 1.2 & 2.12 \\
Coffee & 0.8 & 0.8 & 0.7 & 0.8 & 1.3 & 0.88 \\
Rice & 1.4 & 1.7 & 1.8 & 1.8 & 1.5 & 1.64 \\
Wheat & 0.1 & 0.3 & 0.0 & 0.0 & 0.1 & 0.1 \\
Tobacco & 0.8 & 0.9 & 0.9 & 0.7 & 0.3 & 0.72 \\
Cashew & 1.4 & 1.5 & 1.4 & 1.5 & 1.5 & 1.46 \\
Spices & 0.7 & 0.8 & 0.7 & 0.8 & 0.7 & 0.74 \\
Oil meal & 1.9 & 2.1 & 2.9 & 3.3 & 2.2 & 2.48
\end{tabular}


Fruits \& vegetables

Marine products

Agriculture \&

Allied products $\begin{array}{ll}0.7 & 0.7\end{array}$

2.9

3.3

17.9

18.5
0.6

3.2

16.9
0.6

0.5

0.64

$\begin{array}{cc}3.3 & 3.2 \\ 17.9 & 16.9\end{array}$

3.7

18.1
4.3

16.1
3.48

17.5

Source: Calculated on the basis of data collected from RBI, Handbook of Statistics on Indian Economy.

Table 5: Share of Few Agricultural Commodities in Percentage in India's Total Exports in Post-WTO Period

\begin{tabular}{cccccccccccc}
\hline Commodities & $\mathbf{1 9 9 4 - 9 5}$ & $\mathbf{9 5 - 9 6}$ & $\mathbf{9 6 - 9 7}$ & $\mathbf{9 7 - 9 8}$ & $\mathbf{9 8 - 9 9}$ & $\mathbf{9 9 - 2 0 0 0}$ & $\mathbf{2 0 0 0 - 0 1}$ & $\mathbf{2 0 0 1 - 0 2}$ & $\mathbf{2 0 0 2 - 0 3}$ & 2003-04 & 2004-05 \\
\hline Tea & 1.1 & 1.2 & 1.4 & 1.6 & 1.1 & 1.0 & 0.8 & 0.7 & 0.6 & 0.5 & 0.4 \\
Coffee & 1.4 & 1.2 & 1.3 & 1.2 & 0.9 & 0.6 & 0.5 & 0.4 & 0.4 & 0.3 & 0.3 \\
Rice & 4.2 & 2.6 & 2.6 & 4.4 & 1.9 & 1.4 & 1.5 & 2.2 & 1.4 & 1.8 & 1.3 \\
Wheat & 0.3 & 0.6 & 0.0 & 0.0 & 0.0 & 0.2 & 0.6 & 0.7 & 0.8 & 0.4 & 0.1 \\
Tobacco & 0.8 & 1.0 & 1.1 & 1.1 & 1.1 & 0.8 & 0.7 & 0.7 & 0.5 & 0.5 & 0.5 \\
Cashew & 1.1 & 1.1 & 1.1 & 1.1 & 1.5 & 0.9 & 0.9 & 0.8 & 0.6 & 0.7 & 0.6 \\
Spices & 2.2 & 2.9 & 2.6 & 1.4 & 1.0 & 1.0 & 1.1 & 0.6 & 1.1 & 0.8 & 1.1 \\
Oilseeds & 0.8 & 0.4 & 0.6 & 0.5 & 0.6 & 0.6 & 0.6 & 0.6 & 0.7 & 0.6 & 0.6 \\
$\begin{array}{c}\text { Fruits \& } \\
\text { Vegetables }\end{array}$ & 3.2 & 3.4 & 3.4 & 3.1 & 3.2 & 3.1 & 2.8 & 2.7 & 2.1 & 1.7 & 1.7 \\
Marine & 0.2 & 1.3 & 0.6 & 0.2 & 0.04 & 0.1 & 0.2 & 0.02 & 0.3 & 0.1 & 0.6 \\
$\begin{array}{c}\text { Products } \\
\text { Agriculture \& }\end{array}$ & 19.13 & 20.5 & 18.98 & 18.17 & 15.68 & 13.5 & 13.5 & 12.8 & 11.8 & 10.1 & 9.9 \\
allied Products & & & & & & & & & & & \\
\hline
\end{tabular}

Cont....

Commod- 2005-06 2006-07 2007-08 2008-09 2009-10 2010-11 2011-12 2012-13 2013-14 2014-15 Average ities

\begin{tabular}{cccccccccccc}
\hline Tea & 0.3 & 0.3 & 0.3 & 0.3 & 0.3 & 0.3 & 0.3 & 0.3 & 0.2 & 0.3 & 0.63 \\
Coffee & 0.3 & 0.3 & 0.3 & 0.2 & 0.3 & 0.3 & 0.3 & 0.3 & 0.3 & 0.3 & 0.54 \\
Rice & 1.2 & 1.7 & 1.3 & 1.3 & 0.9 & 1.6 & 2.1 & 2.5 & 2.5 & 2.2 & 2.08 \\
Wheat & 0.0 & 0.0 & 0.0 & 0.0 & 0.0 & 0.1 & 0.6 & 0.5 & 0.0 & 0.3 & 0.2 \\
Tobacco & 0.6 & 0.6 & 0.7 & 0.7 & 0.7 & 0.3 & 0.3 & 0.3 & 0.3 & 0.4 & 0.65 \\
Cashew & 0.4 & 0.3 & 0.3 & 0.3 & 0.2 & 0.3 & 0.2 & 0.3 & 0.3 & 0.3 & 0.63 \\
Spices & 1.0 & 1.2 & 1.2 & 0.9 & 0.9 & 0.9 & 0.9 & 0.8 & 0.8 & 1.0 & 1.21 \\
Oilseeds & 0.6 & 0.5 & 0.6 & 0.7 & 0.5 & 0.8 & 1.0 & 0.9 & 0.4 & 0.2 & 0.61 \\
$\begin{array}{c}\text { Fruits \& } \\
\text { Vegetables }\end{array}$ & 1.4 & 1.1 & 0.8 & 1.2 & 1.0 & 0.4 & 0.6 & 0.7 & 0.7 & 0.8 & 1.86 \\
$\begin{array}{c}\text { Marine } \\
\text { Products }\end{array}$ & 1.1 & 1.3 & 0.3 & 1.1 & 1.1 & 1.1 & 1.2 & 1.6 & 1.8 & 1.8 & 0.76 \\
$\begin{array}{c}\text { Agriculture } \\
\text { \& Allied }\end{array}$ & 10.3 & 11.3 & 9.5 & 10 & 9.9 & 17.19 & 14.1 & 13.79 & 12.66 & 13.17 & 13.62 \\
Products & & & & & & & & & & & \\
\hline
\end{tabular}

Source: Calculated on the basis of data collected from RBI, Handbook of Statistics on Indian Economy. 
The Tables 4 and 5 demonstrates the average percentage share in export of selected agricultural commodities Pre \& Post WTO era. These tables show that there is both positive and negative impact of WTO regime on different agricultural export commodities, for example there is positive impact of WTO on export of Rice, Wheat, Spices, and Fruits \& Vegetables (the export share rose from 1.64, 0.1, 0.74, $0.64 \%$ in the pre WTO period to $2.03,0.2,1.21$, and $1.86 \%$ Rice, Wheat, Spices and fruits \& vegetables in the Post WTO era) but on the other hand there has been negative impact of WTO on some selected agricultural commodity export. For example The average percentage share of export of Tea, Coffee, Tobacco, Cashew, Oil meals, and Marine products has reduced from 2.12, 0.88, 0.72, 1.46, 2.48, 3.48\% in the Pre WTO era to $0.63,0.54,0.65,0.63,0.61,0.76 \%$ in the post WTO period respectively. We also see in these tables that the average share of agricultural exports in total exports has declined from $17.5 \%$ to $13.62 \%$ in the post WTO era. This may be as a result of increase in the share of non agricultural commodity share in India's total export.

Table 6: Compound Annual Growth Rate of value of export of few Agricultural trading Commodities in Pre and Post WTO era

\begin{tabular}{ccc}
\hline Commodities & Pre WTO era (1990-1995) & Post WTO era (1996-2014) \\
\hline Tea & -15.0 & 4.6 \\
Coffee & 24.2 & 5.1 \\
Rice & 10.5 & 12.4 \\
Tobacco & 13.7 & 11.7 \\
Cashew & 12.3 & 4.8 \\
Spices & 10.5 & 14.4 \\
Oil Meals & 13.9 & 9.8 \\
Fruits \& Vegetables & 4.0 & 17.7 \\
Marine Products & 20.4 & 8.2 \\
\hline
\end{tabular}

Source: computed on the basis of data collected from RBI, Handbook of statistics on Indian Economy.

Table 6 shows the CAGR (compound annual growth Rate) of value of few agricultural commodities like Coffee, Tobacco, Cashew, Oil Meals and Marine Products has declined in the post WTO period, Where CAGR of value of tea, rice, spices and fruits \& vegetables has increased in the same period. This means that the WTO has shown both Positive and negative impact or influence on different selected agricultural commodity export in the same period.

Table 7: NPC (Nominal Protection Coefficient) results of Indian major agricultural commodity export share estimated to compare before and after the WTO

\begin{tabular}{ccccc}
\hline \multirow{2}{*}{$\begin{array}{c}\text { Agricultural } \\
\text { Commodities }\end{array}$} & \multicolumn{2}{c}{$\mathbf{1 9 8 5 - 9 4}$} & \multicolumn{2}{c}{$\mathbf{1 9 9 5 - 2 0 1 4}$} \\
\cline { 2 - 5 } & Average & Standard Deviation & Average & Standard Deviation \\
\hline Rice & 1.18 & 0.30 & 1.04 & 0.12 \\
Wheat & 1.81 & 0.33 & 1.24 & 0.33 \\
Coffee & 1.46 & 0.99 & 2.06 & 1.03 \\
Tea & 1.67 & 0.96 & 1.14 & 0.16 \\
Sugar & 2.78 & 0.95 & 1.53 & 0.27
\end{tabular}




\begin{tabular}{ccccc} 
Cashew nuts & 1.15 & 0.12 & 1.10 & 0.10 \\
Ground Nuts & 0.63 & 0.21 & 0.56 & 0.08 \\
Cake of Ground & 1.58 & 0.43 & 1.12 & 0.19 \\
Nuts & & & 0.38 \\
Oil of Ground Nuts & 2.19 & 0.77 & 3.42 & 0.56 \\
Linseeds & 4.37 & 1.69 & 1.63 & 0.38 \\
Oil of Linseeds & 2.14 & 0.42 & 0.96 & 0.26 \\
Cake of Rapeseeds & 1.27 & 0.39 & 1.95 & 0.55 \\
Oil of Rapeseeds & 2.96 & 0.83 & 0.66 & 0.09 \\
Sesame Seeds & 0.84 & 0.14 & 0.41 & 0.09 \\
Oil of Sesame seeds & 0.77 & 0.14 & 2.54 & 0.86 \\
Cake of Coconuts & 3.87 & 0.74 & 0.78 & 0.33 \\
Onion & 0.84 & 0.09 & 0.45 & 0.13 \\
Potato & 0.93 & 0.33 & 1.63 & 0.25 \\
Apple & 2.03 & 0.36 & 0.33 & 0.10 \\
Banana & 0.51 & 0.44 & 1.03 & 0.11 \\
Pepper & 1.04 & 0.08 & 1.34 & 0.58 \\
Rubber & 1.28 & 0.34 & 0.77 & 0.18 \\
Cotton & 0.77 & 0.18 & 1.14 & 0.31 \\
Jute & 1.81 & 1.67 & 0.40 & 0.04 \\
Tobacco & 0.30 & 0.06 & 1.27 & 0.36 \\
Soya bean & 0.92 & 0.15 & 1.19 & 0.34 \\
Cake of Soya bean & 0.97 & 0.06 & 2.50 & 0.42 \\
Oil Of Soya bean & 1.33 & 0.62 & & \\
\hline
\end{tabular}

Source: FAO Data interpretation.

The NPC is a ratio shows the trading agri-commodity is exportable or Importable $\left(\mathrm{NPC}=P i^{d} / \mathrm{Pi}^{w}\right)$ $P_{i}^{d}=$ Domestic price of commodity $i . P_{i}^{w}=$ World reference price of commodity $i$, adjusted for transportation, handling and marketing expenses.

Here, NPC $<1$ indicates the commodity is exportable and NPC $>1$ indicates that the commodity is importable. Other than some notable cases like Ground Nut, Sesame Seeds, Onion, Potato, Banana, Cotton, tobacco and Soya bean most other agricultural trading commodities remained in higher than unity value in the Post WTO period. The value of NPCs of mostly all commodities has gone down in Post WTO period comparing to the Pre WTO era.

The Fig. 1 shows how Indian export has been increasing faster than the Import. In the whole period import was lowest as compare to export was in 2000-01. After 2010 India removed bans on few agricultural commodities export including Wheat, as a result of this export of agri-commodities surged and in 2011 to 120000 crore approx. In the next two years both import and export got doubled. The export reaches 232000 crore and the import became 110000 crore approx. In this time the CAGR of agricultural export and import in the post-WTO period shows that the Agri- export growth rate came down first from $21.78 \%$ (1991-95) to $5.5 \%$ (1996-2000) then again rose to $16.07 \%$ in $2006-10$, and rose faster after that to $31.71 \%$ 
during the next five year. It reveals that agricultural trade liberalisation effected Indian agri-trade adversely in the first ten years of liberalisation and thereafter the agricultural sector become competitive globally and export growth took it pace ${ }^{[16]}$.

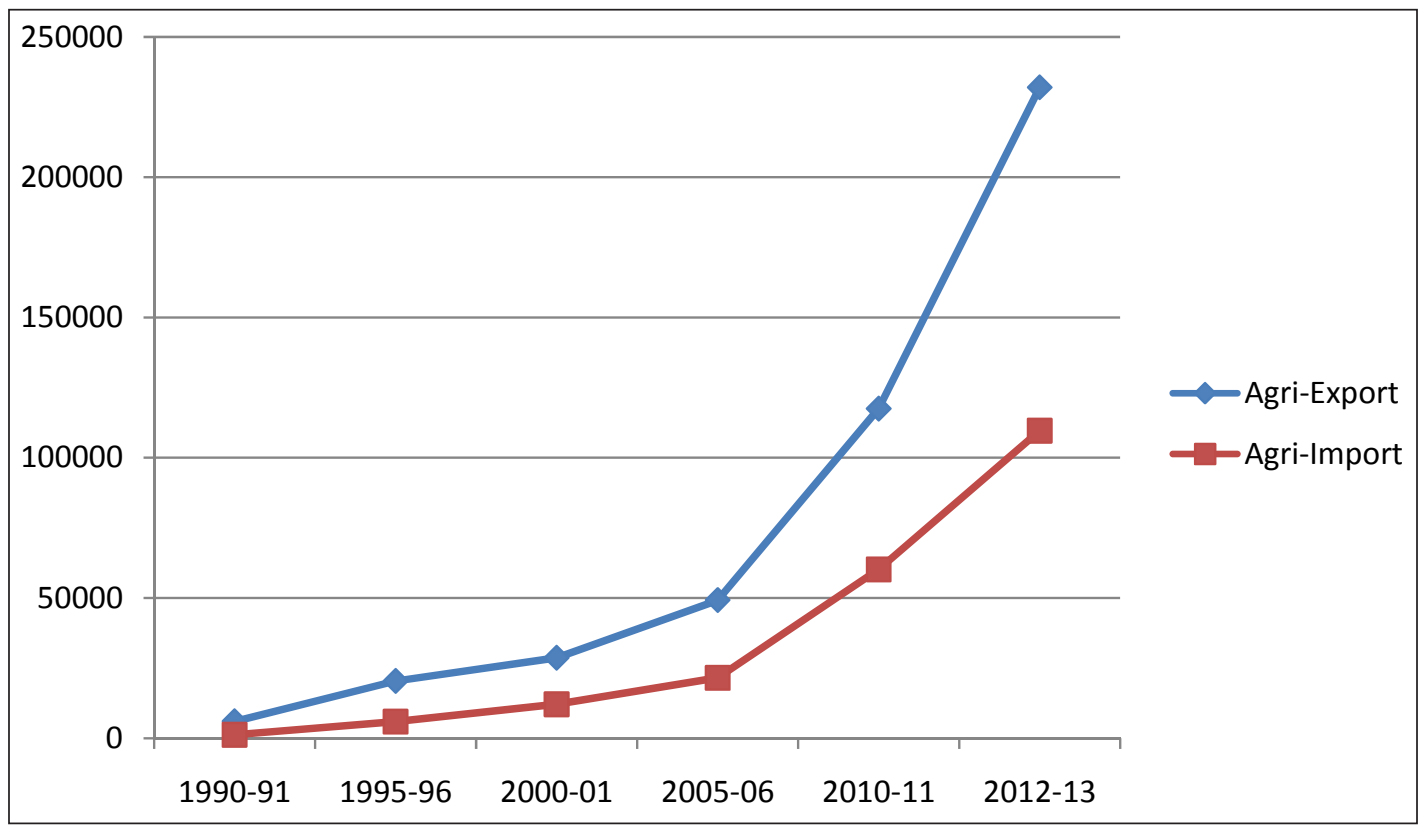

Fig. 1: Agricultural export, import of India from 1990-91 to 2012-13 (During Pre \& Post WTO Era) Amount estimated in thousand crore of Indian rupees

Source: Director General of Commercial Intelligence \& Statistics, Ministry of Commerce, Government of India

Table 8: Several Major destinations for the export of Indian agricultural Commodities during 2014-15

\begin{tabular}{cccccc}
\hline $\begin{array}{c}\text { Importing } \\
\text { Countries }\end{array}$ & $\begin{array}{c}\text { Share in } \\
\text { Percent }\end{array}$ & $\begin{array}{c}\text { Importing } \\
\text { countries }\end{array}$ & $\begin{array}{c}\text { Share in } \\
\text { Percent }\end{array}$ & $\begin{array}{c}\text { Importing } \\
\text { Countries }\end{array}$ & $\begin{array}{c}\text { Share in } \\
\text { Percent }\end{array}$ \\
\hline USA & 11.50 & China & 2.51 & Pakistan & 1.30 \\
Vietnam & 9.28 & Japan & 2.45 & Kuwait & 1.26 \\
Iran & 8.43 & South Korea & 2.01 & Nepal & 1.25 \\
UAE & 4.98 & UK & 1.84 & Germany & 1.20 \\
Saudi Arabia & 4.84 & Belgium & 1.78 & Italy & 1.18 \\
Bangladesh & 3.55 & Netherlands & 1.72 & Russia & 1.16 \\
Malayasia & 3.09 & Benin & 1.42 & Yemen & 1.10 \\
Indonasia & 2.70 & Egypt & 1.40 & Other Countries & 24.12 \\
Thailand & 2.55 & France & 1.38 & & \\
\hline
\end{tabular}

Source: ITC data base, Switzerland. 


\section{CONCLUSION}

From the above discussion and after the analysis of the trend of Indian agricultural export in the pre and post WTO era we see that there has been huge fluctuations occurred in India's agricultural Export and Import in the Post WTO period as compare to the Pre WTO period. The share of agricultural export as compare to total export has gone down drastically in the early phase of trade liberalisation under WTO but it accommodated itself with the international market competition later in the post 2000. After 2012 we found that amount of Export volume has gone high up, and it got doubled as compare to early 2010 data. But the data shows a negative aspect in case of export share of agricultural commodities to countries total export in the post WTO period. The share of agri-export as compare to the total export of India has gone down in the post WTO period though the amount of volume of export has gone multiple times up as compare to the pre WTO period. As it was expected that after the AOA and WTO the amount of Export share of Agricultural commodity would go up and it will help improving country's agri-export, but on the contrary it has fallen during the post WTO period. On the other hand however India's share of agricultural commodity Export in the World has gone up to $1.49 \%$ in the Post WTO period as compare to $0.85 \%$ in the Pre WTO period. This implies that under WTO India's export share in agriculture has improved. In many research studies it is found that there exists divergence in Indian agricultural commodity exports, as in the pre WTO period it is found that India has made effort to specialize in agricultural commodity export in which it has comparative advantage but in the post WTO period no such attempt was made where we can see any specialisation of agricultural commodity export. It implies that the WTO has not laid India to gain expertise in the export of agricultural product where it has comparative advantage. When we go into further analysis of impact of WTO on few selected agricultural trading commodities we came to know that several commodities are there on which WTO positive effect like has impacted , for example commodities like Wheat, Rice, Spices, Fruits \& vegetables have increased their share in export in the post WTO period, while commodities like Tea, coffee, Tobacco, Cashew, Oil Meals, Marine products has shown negative impact of WTO on them, as their export share has fallen down in the post WTO era. Despite that the Indian agricultural export has increased in absolute term in the post WTO period, the average share of agricultural export in total export from India has fallen down from $17.5 \%$ in the Pre WTO period to $13.62 \%$ in the post WTO era, which may be as a result of much increase in the share of non agricultural export in India's total export. Furthermore the value of NPCs of mostly all commodities has gone down in Post WTO period comparing to the Pre WTO era, which implies that exporting capacity or export competitiveness has increased in the Post WTO era.

Thus in conclusion we can say that WTO has a mixed impact on India's Agricultural commodity Export. In one side WTO impacted negatively where many selected agricultural commodities export share has been declined than pre WTO era and at the same time WTO didn't help to gain expertise in agricultural trade, on the other hand it has helped increasing export share of many other agricultural trading commodities and at the same time it has helped India to gain world agricultural export market share by improving India's position in the global agricultural export.

\section{References}

1. Aleandros, N. 1993. Agriculture: Towards 2010, Rome: Food and Agriculture Organization of United Nations ${ }^{[12]}$. 
2. Ahulwalia, Montek. 2002. "Economic Reforms in India Since 1999: Has Gradualism Worked?, Journal of Economics Perspective, 16 ${ }^{[3]}$.

3. Anderson, K. and Tyres R. (1993): "More on Welfare Gains to Developing Countries from Liberalising World Food Trade", Journal of Agricultural Economics, 44(2): 189-204. [13]

4. Anoopkumar, M. (2012). “Commodity Price Instability under Globalization: A Study of India's Plantation Crops”: NRPPD Discussion Paper (13), pp. 1-56. [1]

5. Bhattacharyya, R. (2011). Revealed comparative advantage and competitiveness: A case study for India in horticultural products. [International Conference on Applied Economics, Perugia. 25- 27 August][6]

6. B. Sheshagiri \& G.G. Honkan (2011): "Impact of W.T.O on Indian Agriculture: Performance and Prospects"[10]

7. Deepika, M.G. and Deshpande, R.S. (2003). Trade Policy and Determinants of Trade in Agriculture (Working Paper No.18) [11].

8. Datta, Samar K (2000). "Problems and Prospects of India's Rice Trade in a WTO Regime", Journal of Indian School of Political Economy, 12[5] FAO year Book: (2007)[9].

9. Gill, S.S. and Brar J.S.(1996). "Global Market and Competitiveness of Indian Agriculture: Some Issues," Economic and Political Weekly, August [10], p. [2175][14].

10. Gulati, Ashok and Sharma Ashok (1994). "Agriculture under GATT: What it holds for India". Economic and Political Weekly, 31.[4].

11. Nilotpal, P. (2000), "India and WTO-A Study of the Impact on Indian Economy", [New Delhi, Cipra Books] [15].

12. Rani, Pooja (2015), “A Study of WTO and Agriculture Sector in India”, International Journal of Multidisciplinary Research and Development, ISSN (2349-5979), 2(9); pp. [456-459]. [7]

13. Solanki, Sandeep, P., "Impact of WTO on India's Foreign Trade: "Trends and Prospects", 88th IEA, Annual Conference Volume, Part - I, pp. [537].[8]

14. Tripathi, A. and Prasad, A.R.(2009). Agricultural development in India since in determinants: A study on progress, performance and determinants. Journal of Emerging Knowledge on Emerging Markets, 1(1): 63-92 [2]

15. Tyagi,V.( 2012).India's agriculture: Challenges for Growth \& development in present scenario IJPSS 2(5): [2249-5894][16]

16. Vyas, V.S. (1994). Agricultural Price Policy: Need for Reformulation”, in G.S. Bhalla (Ed.) (1994), [Economic Liberalization and Indian Agriculture, Institute for studies in Industrial Development, New Delhi] [19].

17. World Bank (2014) “World Development Report” [17]

18. World Trade and Development Report (2013): Cancun and Beyond. [New Delhi] [18] 
